\title{
FACTORS AFFECTING MOTIVES FOR HOUSING DEMAND: THE CASE OF A TURKISH PROVINCE
}

\author{
Ömer ALKAN \\ Atatürk University, Department of Econometrics, 25240, Erzurum, Turkey \\ oalkan@atauni.edu.tr \\ Abdulkerim KARAASLAN \\ Atatürk University, Department of Econometrics, 25240, Erzurum, Turkey \\ akkaraaslan@atauni.edu.tr \\ Hayri ABAR \\ Atatürk University, Department of Econometrics, 25240, Erzurum, Turkey \\ hayri@atauni.edu.tr \\ Ali Kemal ÇELíK* \\ Atatürk University, Department of Quantitative Methods, 25240, Erzurum, Turkey \\ akemal.celik@atauni.edu.tr

\section{Erkan OKTAY} \\ Atatürk University, Department of Econometrics, 25240, Erzurum, Turkey \\ erkanoktay@atauni.edu.tr
}

\begin{abstract}
In the contemporary era, housing sector overwhelmingly comes into prominence more than ever along with manifold triggers such as advances in construction technology, migration density from rural to urban areas, restructuring of seismic territories, urban transformation, and substantial changes in the socio-economic structure. The creation of more efficient living areas can be enabled by paying careful attention to the underlying changes, establishing the increase on the well-being, and more specifically, interpreting the reasons for housing demand of potential consumers. In that context, this study aims to determine the factors affecting motives for the housing demand in a Turkish province, Erzurum through a questionnaire. The questionnaire addresses the potential motives for housing demand into four main categories: owner occupancy, children's occupancy, rental income, and investment planning. The cross-sectional data of the questionnaire were analyzed using the multinomial logit model. The estimation results showed that the motives for housing demand were mostly effected by occupation and age of the respondents, however several other factors were found to have a significant effect on their motives. Keywords: Housing, Motives, Housing Demand, Multinomial Logit Model, Erzurum, Turkey.
\end{abstract}

${ }^{*}$ Corresponding author 


\section{Alkan O., Karaaslan A., Abar H., Çelik A.K., Oktay E. FACTORS AFFECTING MOTIVES FOR HOUSING DEMAND: THE CASE OF A TURKISH PROVINCE}

\section{INTRODUCTION}

Housing sets out noteworthy variability with respect to consumer perceived quality and prices, while this disaggregate behavior should be properly appreciated to make an accurate assessment as a means of future housing market policies (Han, 2010). Additionally, housing is adopted as both an investment and consumption good for owner-occupiers, and therefore, basic motives of households' decisions associated with their dwellings are their investment and consumption considerations (Özdemir-Sarı, 2014). The housing sector contributes to a wide range of dimensions such like financing, upgrading, repairs, management, valuation, taxation and population (Yetgin \& Lepkova, 2007).

Housing sector development in the developing countries has been subject to greater internationalism and it is increasingly taking the more comprehensive approach characterized by demographical and developmental factors (Pugh, 2001). Turkey has been experiencing a rapid process of population growth and urbanization in recent years and therefore several ways of rapid housing systems were exercised to solve the housing shortage problem (Altaş \& Özsoy, 1998). A housing boom was considered as the basic characteristic of Turkey's formal housing sector from the beginning of urbanization in the 1950s until the late 1970s, while during the 1950s industrialization attempts and the increasing rate of urbanization ensured an occasion of consistenly increasing demand for urban and land housing. Especially, massive migratory flows to a very few metropolitian centres were the initial determinant of growth in housing demand (Baharoglu, 1995). Between 1950 and 1980, Turkey suffered from high and sustained inflation and the supply of urban land and housing was limited by financial, technical, and institutional constraints. This circumstance led to the direction of the limited government funds for subsidizing the development of industry, not housing. Particularly, public investment was less than 10 percent of total housing investment, leaving more than 90 percent to the private sector (Yonder, 1987). Before 1980, the effect of cooperatives on the production of social housing was quiet low in the formal housing sector, while their contribution was $5 \%$ of total housing supply until the 1970 s, however their share in the total housing production increased to 10\%-15\% between 1970 and 1980 (Turk \& Altes, 2013). In 1980, economic regulations by the government led to housing deficit increase and housing investment decrease. When the government policies encouraged the improvement of the housing sector, not surprisingly, investment in housing increased. In that period, the establishment of the Mass Housing Fund and remarkable changes that support new dwelling unit construction were the most prominent initiatives (Yetgin \& Lepkova, 2007).

Many factors can be considered to be capable of having significant impacts on housing demand such as several concerns for the future, housing investment, achieving rental income, etc. The economics of 
housing demand is gradually evolving over the past decades, and consequently major improvements in measuring price and income terms, the joint modelling of tenure choice, mobility and demand, the availability of large databases can be regarded as the divergent determinants of the housing demand estimates (Goodman, 2002). For instance, in any time period household making a housing preference investigates the spatial locations of each type of housing and market prices of housing types at the corresponding locations (Quigley, 1976). In addition, the housing purchase at a given time will be relevant to both recent and the further prices and incomes, due to intertemporal life-time optimization that specifies the purchase of many types of goods and high transactions costs of changing the amount of purchased housing (Goodman, 1990). The objective of this study is to determine the factors affecting the motives for housing demand using a statistical analysis.

\section{LITERATURE REVIEW}

A great number of studies has devoted to the housing demand and its determinants using different econometrical and/or statistical analyses. Feinstein \& McFadden (1987) investigated the pattern of housing mobility amongst the elderly households and developed a Lagrange Multiplier test for unobserved heterogeneity amongst them. They suggested that wealthier households are less likely to move and downsize, family composition or retirement status significantly increase the likelihood of a move. Rapaport (1997) developed an econometric model that incorporates through several factors and estimated the model using a sample of Florida households. Kenny (1999) used the cointegration analysis to identify both the demand and supply sides of the lrish housing market and he suggested that in the long-run the demand side of the market can be modelled using a stable relationship between various indicators. Kan (2000) developed a dynamic random effects simultaneous equation model to estimate household tenure choice decision based on the panel data. Börsch-Supan, Heiss \& Seko (2001) applied a mixed logit model that allows for a flexible substition pattern among unobservable characteristics to analyze housing demand in Germany and Japan. Goodman (2002) modelled demand by owner-occupied housing stayers using American Housing Survey to provide a panel of household stayers for a metropolitan area. Goodman (2003) developed a model on the own-rent, move-stay, and length-of-stay decisions as multi-period optimization in the presence of transaction costs using American Housing Survey data and the results indicated that income and value-rent measures in different years have significant impacts on housing demand. Zabel (2004) also modelled housing demand as a continuous quantity that represents the flow of housing services using the data from National version of the American Housing Survey for 1993 and 2001. Dusancky \& Koç (2007) performed an econometric analysis of housing demand data from Florida and they found that an 
increase in housing prices increased the demand for owner-occupied housing services. Barrios Garcia \& Rodríguez Hernández (2008) presented a study of housing demand in Spain with respect to the type of tenure and building using a mixed logit model. Ng, Skitmore \& Wong (2008) established private housing demand forecast using genetic algorithms and linear regression analysis and their findings indicated this integrated model provides the most accurate forecasts and over a longer time horizon. Han (2010) used a multinomial logit model, hereafter MNLM, to investigate the impact of household characteristics, such as income, size and age composition, on the choice of dwelling, specified by location, size and unit price in housing demand in Shangai, China. Van Ommoren \& Koopman (2011) proposed an alternative method to hedonic price approach that allows to estimate the renters' marginal willingness to pay for apartment characteristics based on residential mobility. Attanasio et al. (2012) modelled individual demand for housing over the life cycle, and showed the aggregate implications of the behavior. Ahmad, Choi \& Ko (2013) estimated qualitative and quantitative demand for housing using household survey in Delhi and they indicated that housing demand is inelastic with respect to price and income. Cesa-Bianchi (2013) investigated the international spillovers of housing demand shocks on real economic activity. Tsai (2013) observed whether the self-correction pattern driven by housing demand occurs and whether it can explain the housing dynamics using the data of Taiwan housing market and she revealed that when the prices rise, housing affordability decreases, followed by reduction in selfoccupancy housing demand.

\section{MULTINOMIAL LOGIT MODEL}

There are many circumstances in which the economic outcome is a discrete choice among a set of alternatives, rather than a continuous measure of some event, such as labor participation, the decision of a major purchase, or voting in an election, occupational field chosen by an individual, opinions of a certain type of legislation, etc. Qualitative response models are special cases in which the dependent variable is an indicator of a discrete choice (Greene, 2008). Since social scientists have always concerned with the choice or decision between mutually exclusive options, various applications of qualitative response models are increasingly growing in econometrical analysis. Particularly, multiple outcome models are qualitative response models in which the dependent variable takes more than two values and these models can be subdivided into models involving ordered and unordered outcomes. A model where the outcome is unordered can be easily estimated by logit models and so this model is frequently referred to as the MNLM (Borooah, 2002). 
Let a sample of $n$ observations is classified into $k$ mutually and exhaustive categories with respect to the specified $\Pi=\left(\pi_{1}, \pi_{2}, \ldots, \pi_{k}\right)$ probabilities. Additionally, let $n_{i}$ be the resulting observed frequencies in each of the $k$ classes, then the joint distribution for the random variables $n_{1}, n_{2}, \ldots, n_{k}$, the observed frequencies, is given by

$P(n, \Pi)=\frac{n ! \pi_{1}^{n_{1}} \pi_{2}{ }^{n_{n}} \ldots \pi_{k}{ }^{n_{k}}}{n_{i} ! n_{2} ! \ldots n_{k} !}=n ! \prod_{i=1}^{k} \frac{\pi_{k}{ }^{n_{k}}}{n_{i} !}$

where $\pi_{i}>0, \sum x_{i}=1, \sum_{i=1}^{k} n_{i}=n$, and $n=n_{1}, n_{2}, \ldots, n_{k}$ is a random vector which can take on any value for which

(i) $0 \leq n_{i} \leq n$ for $i=1,2, \ldots, k$

(ii) $\sum n_{i}=n$

(iii) $n_{r}=n-\sum_{i=1 \neq r}^{k} n_{i}$

The expression in Equation (1) is known as the multinomial distribution (Lawal, 2003).

The MNLM is the most frequently used nominal regression model when the categories are assumed to be unordered and it can be thought of as simultaneously estimating binary logits for all comparisons among the dependent categories (Long \& Freese, 2001). The MNLM offers an appropriate closed form for the discrete choice probabilities without any requirement of multivariate integration. Additionally, choice conditions involving many alternatives can be evaluated in a computationally convenient matter (Hausman \& McFadden, 1984). In the multinomial logit model, there are any number $S$ of alternative outcomes or states with $s=1,2, \ldots, S$, in which the underlying states cover all possible outcomes, if necessary by the addition of a residual category as a means of disjoint and exhaustive property (Cramer, 2003). Suppose that there is $n$ independent observation with $p$ explanatory variables and the qualitative response variable has $k$ categories. In the multinomial case, one of the categories is considered the base level and all the logits are constructed relative to the base category. When category $k$ is taken as a base category, and let $\pi_{j}$ be the multinomial probability of an observation falling in the $j$ th category, then the MNLM is:

$$
\begin{gathered}
\log \left(\frac{\pi_{j}\left(x_{i}\right)}{\pi_{k}\left(x_{k}\right)}\right)=\beta_{0 j}+\beta_{1 j} x_{1 i}+\beta_{2 j} x_{2 i}+\cdots+\beta_{p j} x_{p i j} ; \quad j=1_{j} 2_{j \cdots}(k-1)(2) \\
i=1,2, \ldots, n
\end{gathered}
$$


Since all the $\pi$ 's add to the unity, Equation (2) reduces to

$\log \left(\pi_{j}\left(x_{i}\right)=\frac{\exp \left(\beta_{0 j}+\beta_{1 j} x_{1 i}+\beta_{2 j} x_{2 i}+\cdots+\beta_{p j} x_{p i}\right)}{1+\sum_{j=1}^{k-1} \exp \left(\beta_{0 j}+\beta_{1 j} x_{1 i}+\beta_{2 j} x_{2 i}+\cdots+\beta_{p j} x_{p i}\right)}\right.$

for $j=1,2, \ldots,(k-1)$, where the model parameters are estimated by the maximum likelihood method (Chatterjee \& Hadi, 2006).

Although the variables used in regression formulas usually take values over some continuous range, several independent variables that are restricted to taking on two or more district values may also be used. In this sense, dummy variables are especially beneficial when dealing with qualitative data. Thus, one can indicate how dummy variables are able to be used in the regression to account for the fact that observations within a given category are relevant to one set of regression parameters while observations in a second or third category are relevant to different regression parameters (Pindyck \& Rubinfeld, 1981). Let each of the $N$ observations on the dependent variable $Y_{i}(i=1, \ldots, N)$ is treated as a single draw from a multinomial distribution with $M$ outcomes and define a dummy variable $\delta_{i j}=1$ if person $i$ makes choice $j, \delta_{i j}=0$, otherwise $(j=1, \ldots, N)$, then the likelihood of this sample will be

$L=\prod_{i=1}^{N} \prod_{j=1}^{M}\left[P\left(Y_{i}=j\right)\right]^{\delta_{i j}} \Rightarrow \log L=\sum_{i=1}^{N} \sum_{j=1}^{M} \delta_{i j} P\left(Y_{i j}=1\right)$

where the parameter estimates $\vec{\beta}_{j r}(j=1, \ldots, M ; r=1, \ldots, R)$ are chosen to maximize the likelihood function (Borooah, 2002).

\section{INDEPENDENCE OF IRRELEVANT ALTERNATIVES ASSUMPTION}

Standard econometric models impose strict assumptions on the degree of independence among the unobserved influences on various choices and the most well-known is adopted as the independence of irrelevant alternatives, hereafter IIA, assumption of the MNLM. The IIA can be briefly defined as the requirement of the stochastic components of utility attached to the alternatives be independent (Small, 1987). The conceptual background of the IIA can be defined as 
$P\left(i \mid z_{y}, C_{y} \beta\right) \equiv P\left(i \mid z_{z}, A_{y} \beta\right) P\left(A \mid z_{3} C_{y} \beta\right)$

where $C=\{1, \ldots, \mathcal{J}\}$ denotes a finite choice set; $i$ and $j$ denote alternatives in $C ; z$ denotes the attributes of $C ; \beta$ denotes a $K$-vector of taste parameters; the condition $i \in A \subseteq C$ and

$P\left(A_{y} z_{j}, C_{y} \beta\right)=\sum_{j \in A} P\left(j \mid z_{y} C_{y} \beta\right)$

The IIA assumption basically implies that the model can be estimated from data on binomial choices or by restricting attention to choice within a limited subset of the full choice model, so it employs to facilitate the estimation and forecasting (Hausman \& McFadden, 1984).

Choice set partitioning tests and model-based tests are considered as two major tests that can be used to test for violations of the IIA assumption. Choice set partitioning tests perform to compare the results from the full MNLM estimated with all outcomes to the results from a restricted estimation that includes only some of the outcomes and the IIA assumption holds when the estimated coefficients of the underlying model are statistically similar to the restricted estimation. Otherwise, model-based tests are obtained by estimating a more general model that does not impose the IIA assumption and testing constraints that lead to IIA (Cheng \& Long, 2007).

\section{METHODOLOGY AND THE DATA}

In order to obtain the data set of this study, a questionnaire was conducted among households in Erzurum city, northeastern of Turkey. According to the results of 2011 Address-Based Population Registration System, the total population of Erzurum city center and its districsts was 382,383 and particularly, the number of people over the age of 18 was 246,146 (TurkStat, 2011). The underlying questionnaire was conducted among the people over the age 18 to obtain more plausible outcome. The relevant sample size of the questionnaire was calculated with respect to the following formula

$$
n=\frac{N P Q Z^{2}}{(N-1) d^{2}+P Q Z^{2}}
$$

Where $n$ denotes the sample size; $N$ denotes the population size (herein the number of people over the age of 18); $P$ equals to the propability of the occurrence for a given event; $Q$ equals to $1-P$; $Z$ denotes the test statistic under the $(1-a) \%$ significance level; and finally $d$ denotes the tolerance. In this respect, the minimum representative sample size of the survey can be calculated as follows (Özer, 2004): 


$$
n=\frac{(246,146)(0.5)(0.5)(1.96)^{2}}{(246,146-1)(0.05)^{2}+(0.5)(0.5)(1.96)^{2}} \cong 384
$$

During the data collection procedure, 1,372 of 3,500 questionnaires were transformed and coded to a convenient computer-ready form, which preciously exceeds the number of objective minimum sample size. Table 1 indicates the descriptive statistics of potential motives for the housing demand in Erzurum city. The dependent variable of this study was the potential motives for the housing demand. The underlying variable was classified into four categorizes: (1) owner occupancy, (2) children's occupancy, (3) rental income, (4) investment purpose. The independent variables of the study were evaluated in eight main components such as gender, age group, head of household's occupation, spouse's occupation, monthly income in Turkish liras, the number of individuals in the family, the ownership of the current house, and the number of real estate ownership.

\begin{tabular}{|c|c|c|c|c|c|}
\hline VARIABLES & $f$ & $\%$ & VARIABLES & $f$ & $\%$ \\
\hline GENDER & & & MONTHLY INCOME & & \\
\hline Male & 1123 & 81.9 & $0-750 \mathrm{TL}$ & 70 & 5.1 \\
\hline Female & 249 & 18.1 & $751-1500 \mathrm{TL}$ & 488 & 35.6 \\
\hline AGE GROUP & & & $1501-2250 \mathrm{TL}$ & 413 & 30.1 \\
\hline $18-25$ & 95 & 6.9 & $2251-3000 \mathrm{TL}$ & 216 & 15.1 \\
\hline $26-33$ & 275 & 20.1 & 3301 TL and higher & 183 & 13.4 \\
\hline $34-41$ & 349 & 25.5 & HOUSEHOLD SIZE & & \\
\hline $42-49$ & 315 & 23.0 & One individual & 31 & 2.3 \\
\hline \multirow{2}{*}{59 and older } & $\begin{array}{r}237 \\
98\end{array}$ & \multirow{2}{*}{7.2} & Two individuals & 121 & 8.9 \\
\hline & 98 & & Three individuals & 246 & 18.0 \\
\hline OCCUPATION & & & Four individuals & 477 & 34.9 \\
\hline Officer & 432 & 31.5 & Five and more ind. & 490 & 35.9 \\
\hline Craftsman & 333 & 24.3 & MOTIVES FOR & & \\
\hline Worker & 159 & 11.6 & HOUSING DEMAND & & \\
\hline Self-employment & 145 & 10.6 & Owner-occupancy & 687 & 50.3 \\
\hline Farmer & 39 & 2.8 & Children's occupancy & 306 & 22.4 \\
\hline Retired & 145 & 10.6 & Rental income & 162 & 11.9 \\
\hline Housewife/unemployed & 118 & 8.6 & Investment & 211 & 15.4 \\
\hline SPOUSE'S OCCUPATION & & & TENURE TYPE & & \\
\hline Officer & 207 & 16.7 & Owner-occupier & 768 & 56.2 \\
\hline Craftsman & 40 & 3.2 & Renter & 473 & 34.6 \\
\hline $\begin{array}{l}\text { Worker } \\
\text { Self-employment }\end{array}$ & 46 & $\begin{array}{l}3.7 \\
39\end{array}$ & Dwelling-house & 104 & 7.6 \\
\hline $\begin{array}{l}\text { Self-employment } \\
\text { Farmer }\end{array}$ & $\begin{array}{r}49 \\
5\end{array}$ & $\begin{array}{l}3.9 \\
0.4\end{array}$ & Other & 21 & 1.5 \\
\hline Retired & 48 & 3.9 & & & \\
\hline Housewife/unemployed & 847 & 68.2 & & & \\
\hline MULTI-OWNERSHIP & & & & & \\
\hline None & 524 & 40.2 & & & \\
\hline One & 535 & 41.1 & & & \\
\hline Two & 148 & 11.4 & & & \\
\hline Three & 75 & 5.8 & & & \\
\hline Four or more & 21 & 1.6 & & & \\
\hline
\end{tabular}


As shown in Table 1, more than $80 \%$ of the respondents were men; approximately $70 \%$ of them were aged between 26 and 49 ; more than half of them were officers or craftsmen; approximately $70 \%$ of their spouses were housewives or unemployed. Furthermore, the monthly income of more than $70 \%$ of the respondents were between 751 and 2250 Turkish liras (TL); there were four or more individuals in more than 70 of the respondents' family; nearly $60 \%$ of them were owner-occupiers; and more than $80 \%$ of them had currently one or no real estate.

\section{FITTING THE MNLM AND MAXIMUM LIKELIHOOD ESTIMATION}

As the dependent variable of this study involve four unordered categories, the data were analyzed using the MNLM. Table 2 presents the detailed description of the dependent and independent variables used in the MNLM model being fitted. For qualitative variables, all categories were defined as dummy variables to observe the real impact of each categories on the potential motives for housing demand of the respondents. However, the number of individuals and the number of real estates were selected as continuous variables. Several categories were integrated to avoid multicollinearity and to achieve unbiased outcome.

TABLE 2 - DESCRIPTION OF THE VARIABLES USED IN THE MNLM MODEL BEING FITTED

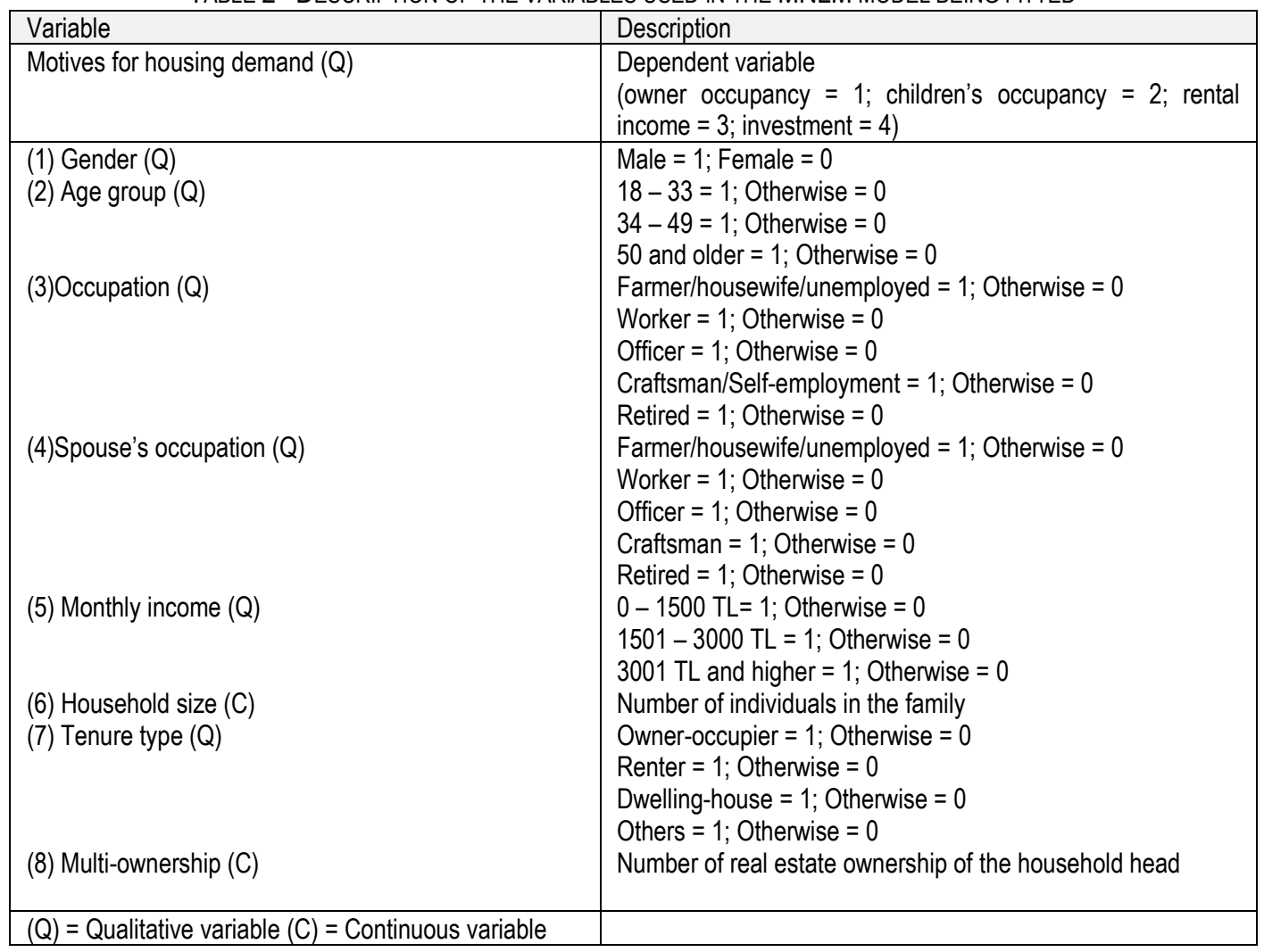


Table 3 exhibits the MNLM estimation results of factors affecting the potential motives for housing demand of the respondents in Erzurum city. The Pseudo- $\chi^{2}$ value of the estimated model was statistically significant $(p<.01)$ with a log-likelihood value of -1261.749 . The empirical results of the MNLM model can be interpreted through relative risk ratios, hereafter $R R R$, which can be evaluated like odds ratios.

TABLE 3 - MNLM ESTIMATION OF FACTORS AFFECTING THE POTENTIAL MOTIVES FOR HOUSING DEMAND

\begin{tabular}{|c|c|c|c|c|c|}
\hline Independent variable & RRR & Std. Err. & $z$ & Sig. & $[95 \% \mathrm{CI}]]$ \\
\hline \multicolumn{6}{|l|}{$\begin{array}{l}\text { Children's occupancy } \\
\text { (Base owner-occupancy) } \\
\text { (1) Gender }\end{array}$} \\
\hline \multicolumn{6}{|l|}{ (2) Age group (base $18-33$ ) } \\
\hline $34-49$ & 5.14 & 1.452 & 5.80 & $0.000^{*}$ & $2.96-8.94$ \\
\hline \multicolumn{6}{|c|}{$\begin{array}{l}\text { (3) Occupation } \\
\text { (base farmer/housewife/unemployed) }\end{array}$} \\
\hline Worker & 1.98 & 0.738 & 1.82 & $0.068^{* \star *}$ & $0.95-4.11$ \\
\hline Officer & 2.25 & 0.770 & 2.38 & $0.017^{* *}$ & $1.15-4.40$ \\
\hline Craftsman/Self-employment & 1.61 & 0.530 & 1.46 & 0.145 & $0.85-3.07$ \\
\hline Retired & 2.83 & 1.071 & 2.75 & $0.006^{* *}$ & $1.35-5.94$ \\
\hline \multicolumn{6}{|c|}{$\begin{array}{l}\text { (4) Spouse's occupation } \\
\text { (base farmer/housewife/unemployed) }\end{array}$} \\
\hline Worker & 0.71 & 0.381 & -0.63 & 0.526 & $0.25-2.03$ \\
\hline Officer & 1.03 & 0.335 & 0.10 & 0.923 & $0.55-1.9$ \\
\hline Crafstman/Self-employment & 2.12 & 0.841 & 1.90 & $0.058^{* * *}$ & $0.97-4.6$ \\
\hline Retired & 1.40 & 0.616 & 0.76 & 0.448 & $0.59-3.3$ \\
\hline \multicolumn{6}{|c|}{ (5) Monthly income (base $0-1500 \mathrm{TL}$ ) } \\
\hline $1501-3000 \mathrm{TL}$ & 1.02 & 0.203 & 0.08 & 0.939 & $0.69-1.5$ \\
\hline 3001 TL and higher & 0.91 & 0.309 & -0.27 & 0.788 & $0.47-1.7$ \\
\hline (6) Household size & 1.48 & 0.141 & 4.15 & $0.000^{*}$ & $1.23-1.7$ \\
\hline \multicolumn{6}{|c|}{ (7) Tenure type (base owner-occupier) } \\
\hline Renter & 0.13 & 0.029 & -9.04 & $0.000^{*}$ & $0.08-0.2$ \\
\hline Others & 0.27 & 0.091 & -3.91 & $0.000^{*}$ & $0.14-0.5$ \\
\hline (8) Multi-ownership & 1.16 & 0.120 & 1.47 & 0.142 & $0.95-1.4$ \\
\hline \multicolumn{6}{|c|}{$\begin{array}{l}\text { Rental income (Base Owner-occupancy) } \\
\text { (1) Gender }\end{array}$} \\
\hline $\begin{array}{l}\text { Male } \\
\text { (2) Age group (base 18 - 33) }\end{array}$ & \multicolumn{4}{|c|}{ (2) Age group (base $18-33$ ) } & $0.28-0.9$ \\
\hline $34-49$ & 2.48 & 0.653 & 3.45 & $0.001^{*}$ & $1.48-4.1$ \\
\hline \multicolumn{6}{|c|}{$\begin{array}{l}\text { (3) Occupation } \\
\text { (base farmer/housewife/unemploved) }\end{array}$} \\
\hline Worker & 2.73 & 1.413 & 1.94 & $0.052^{* * *}$ & $0.99-7.5$ \\
\hline Officer & 2.83 & 1.268 & 2.32 & $0.020^{* *}$ & $1.18-6.8$ \\
\hline Craftsman/Self-employment & 3.62 & 1.600 & 2.91 & $0.004^{*}$ & $1.52-8.6$ \\
\hline Retired & 5.40 & 2.935 & 3.10 & $0.002^{*}$ & $1.86-15$ \\
\hline \multicolumn{6}{|c|}{$\begin{array}{l}\text { (4) Spouse's occupation } \\
\text { (base farmer/housewife/unemployed) }\end{array}$} \\
\hline Worker & 0.68 & 0.469 & -0.56 & 0.572 & $0.17-2.6$ \\
\hline Officer & 1.03 & 0.359 & 0.08 & 0.934 & $0.52-2.0$ \\
\hline Crafstman/Self-employment & 2.11 & 0.899 & 1.76 & $0.079^{\star \star *}$ & $0.92-4.8$ \\
\hline Retired & 0.34 & 0.279 & -1.32 & 0.188 & $0.07-1.6$ \\
\hline \multicolumn{6}{|c|}{ (5) Monthly income (base 0 - $1500 \mathrm{TL}$ ) } \\
\hline $1501-3000 \mathrm{TL}$ & 2.23 & 0.563 & 3.19 & $0.001^{*}$ & $1.36-3.6$ \\
\hline 3001 TL and higher & 2.10 & 0.800 & 1.95 & $0.052^{* * *}$ & $0.99-4.4$ \\
\hline (6) Household size & 1.01 & 0.107 & 0.09 & 0.929 & $0.82-1.2$ \\
\hline
\end{tabular}


Alkan O., Karaaslan A., Abar H., Çelik A.K., Oktay E. FACTORS AFFECTING MOTIVES FOR HOUSING DEMAND: THE CASE OF A TURKISH PROVINCE

\begin{tabular}{|c|c|c|c|c|c|}
\hline Independent variable & RRR & Std. Err. & $z$ & Sig. & $[95 \% \mathrm{Cl}]]$ \\
\hline \multicolumn{6}{|c|}{ (7) Tenure type (base owner-occupier) } \\
\hline Renter & 0.07 & 0.024 & -7.57 & $0.000^{*}$ & $0.03-0.1$ \\
\hline Others & 0.61 & 0.194 & -1.56 & 0.120 & $0.33-1.1$ \\
\hline (8) Multi-ownership & 1.50 & 0.167 & 3.67 & $0.000^{*}$ & $1.21-1.8$ \\
\hline \multicolumn{6}{|l|}{ Investment (Base owner-occupancy) } \\
\hline \multicolumn{6}{|l|}{ (1) Gender } \\
\hline Male & 0.88 & 0.264 & -0.41 & $0.000^{*}$ & $0.49-1.5$ \\
\hline \multicolumn{6}{|l|}{ (2) Age group (base $18-33$ ) } \\
\hline $34-49$ & 1.96 & 0.450 & 2.94 & $0.003^{*}$ & $1.25-3.0$ \\
\hline 50 and older & 1.36 & 0.431 & 0.96 & 0.335 & $0.73-2.5$ \\
\hline \multicolumn{6}{|c|}{$\begin{array}{l}\text { (3) Occupation } \\
\text { (base farmer/housewife/unemployed) }\end{array}$} \\
\hline Worker & 2.61 & 1.347 & 1.85 & $0.064^{* * *}$ & $0.95-7.1$ \\
\hline Officer & 3.03 & 1.353 & 2.49 & $0.013^{* *}$ & $1.26-7.2$ \\
\hline Craftsman/Self-employment & 4.99 & 2.193 & 3.66 & $0.000^{*}$ & $2.11-11$. \\
\hline Retired & 5.04 & 2.786 & 2.93 & $0.003^{*}$ & $1.71-14$ \\
\hline \multicolumn{6}{|c|}{$\begin{array}{l}\text { (4) Spouse's occupation } \\
\text { (base farmer/housewife/unemployed) }\end{array}$} \\
\hline Worker & 0.95 & 0.583 & -0.09 & 0.930 & $0.28-3.1$ \\
\hline Officer & 1.78 & 0.539 & 1.90 & $0.057^{\star * *}$ & $0.98-3.2$ \\
\hline Crafstman/Self-employment & 1.25 & 0.571 & 0.48 & 0.628 & $0.51-3.0$ \\
\hline Retired & 1.84 & 1.005 & 1.11 & 0.265 & $0.63-5.3$ \\
\hline \multicolumn{6}{|c|}{ (5) Monthly income (base 0 - $1500 \mathrm{TL}$ ) } \\
\hline $1501-3000 \mathrm{TL}$ & 3.51 & 0.835 & 5.29 & $0.000^{*}$ & $2.20-5.6$ \\
\hline 3001 TL orhigher & 2.89 & 1.026 & 2.98 & $0.003^{*}$ & $1.44-5.8$ \\
\hline (6) Household size & 1.07 & 0.105 & 0.69 & 0.493 & $1.14-1.7$ \\
\hline \multicolumn{6}{|l|}{ (7) Tenure type (base owner-occupier) } \\
\hline Renter & 0.11 & 0.029 & -8.49 & $0.000^{*}$ & $0.07-0.1$ \\
\hline Others & 0.37 & 0.119 & -3.09 & $0.002^{*}$ & $0.19-0.6$ \\
\hline (8) Multi-ownership & 1.07 & 0.148 & 3.19 & $0.001^{*}$ & $0.88-1.3$ \\
\hline \multicolumn{6}{|l|}{ Number of observations $=1372$} \\
\hline \multicolumn{6}{|l|}{ Log-likelihood = -1261.749 } \\
\hline \multicolumn{6}{|l|}{$\operatorname{LR} \chi^{2}(51)=670.03$} \\
\hline \multicolumn{6}{|l|}{ Prob $>\chi^{2}=0.000$} \\
\hline Pseudo $R^{2}=0.2090$ & & & & & \\
\hline
\end{tabular}

${ }^{*}$ Significant at $1 \%$ level ${ }^{*}$ Significant at $5 \%$ level ${ }^{* *}$ Significant at $10 \%$ level

\section{TEST OF THE IIA ASSUMPTION}

The null hypothesis to test the IIA assumption should be as follows:

$H_{0^{\prime}}$ Odds (Outcome-J versus Outcome-K) are independent of other alternatives.

Table 4 represents the result of test of IIA assumption for the MNLM being fitted. As shown in Table 4, the MNLM model supports the null hypothesis and does not violate the IIA assumption. 
Alkan O., Karaaslan A., Abar H., Çelik A.K., Oktay E.

FACTORS AFFECTING MOTIVES FOR HOUSING DEMAND: THE CASE OF A TURKISH PROVINCE

TABLE 4 - TEST OF THE IIA ASSUMPTION

\begin{tabular}{|c|c|c|c|c|}
\hline Dependent variable & $\chi^{2}$ & d.f. & $P>\chi^{2}$ & Result \\
\hline Children's occupancy & 27.178 & 36 & 0.855 & for $H_{0}$ \\
\hline Rental income & 33.778 & 36 & 0.575 & for $H_{0}$ \\
\hline Investment & 37.536 & 36 & 0.399 & for $H_{0}$ \\
\hline
\end{tabular}

\subsection{The Multicollinearity Test}

Perfect multicollinearity implies that none of the independent variables is perfectly correlated with another independent variable or linear combination of other independent variables, and the absence of perfect multicollinearity is required to achieve the best linear unbiased estimates for a multiple regression model (Lewis-Beck, 1980). The multicollinearity test was performed to the MNLM model being fitted, by evaluating the variance inflation factor, hereafter VIF, values of independent variables. In principal, variables which have VIF values more than 10 are considered as they lead to multicollinearity problem and biased results. As shown in Table 5, none of the risk factors have VIF values more than 10 and it can be suggested the MNLM being fitted does not have serious multicollinearity problem.

TABLE 5 - MULTICOLLINEARITY TEST

\begin{tabular}{lcc}
\hline Variable & VIF & $1 /$ VIF \\
\hline $\begin{array}{l}\text { (1) Gender } \\
\text { Male }\end{array}$ & 1.81 & 0.552 \\
(2) Age group & 1.88 & 0.533 \\
$34-49$ & 2.49 & 0.401 \\
50 and older & & \\
(3) Occupation & 2.15 & 0.466 \\
Worker & 3.62 & 0.276 \\
Officer & 3.69 & 0.271 \\
Craftsman/Self-employment & 2.39 & 0.419 \\
Retired & & \\
(4) Spouse's occupation & 1.50 & 0.669 \\
Worker & 2.88 & 0.347 \\
Officer & 1.91 & 0.523 \\
Craftsman/Self-employment & 1.66 & 0.604 \\
Retired & & \\
(5) Monthly income & 1.43 & 0.698 \\
1501 -3000 TL & 1.88 & 0.533 \\
3001 TL and higher & 1.18 & 0.844 \\
(6) Number of individuals & & \\
(7) Ownership of the house & 1.39 & 0.717 \\
Renter & 1.24 & 0.805 \\
Others & 1.33 & 0.751 \\
(8) Number of real estate ownership & & \\
& $\mathbf{2 . 1 5}$ & \\
\hline Mean VIF & & \\
\hline
\end{tabular}




\subsection{Goodness-of-fit test}

Table 6 presents the measures of fit values of the MNLM model being fitted through several criteria.As the model has very small and very negative Akaike and Bayesian Information Criteria, respectively, it may be suggested that the model has acceptable measures of fit.

TABLE 6 - MEASURES OF FIT TEST

\begin{tabular}{|l|r|}
\hline Measures of fit criteria & Value \\
\hline Log-likelihood intercept only & -1596.765 \\
\hline Log-likelihood full model & -1256.788 \\
\hline $\mathrm{LR}(54)$ & 679.954 \\
\hline$P>\mathrm{LR}$ & 0.000 \\
\hline McFadden'sR ${ }^{2}$ & 0.213 \\
\hline AdjustedR ${ }^{2}$ & 0.177 \\
\hline Akaike information criteria & 2.029 \\
\hline Bayesian information criteria & -6358.261 \\
\hline BIC' & -292.975 \\
\hline
\end{tabular}

On the other hand, Table 7 indicates the goodness-of-fit test results of the MNLM model being fitted. The model had an acceptable goodness-of-fit, because the probability of Pearson $\chi^{2}$ is more than 0.05 .

TABLE 7 - GOODNESS-OF-FIT TEST

\begin{tabular}{|l|r|}
\hline Dependent variable & Motives for housing demand \\
\hline Number of observations & 1372 \\
\hline Reference category & Owner-occupancy \\
\hline Pearson $\chi^{2}$ test statistic & 27.016 \\
\hline$P>\chi^{2}$ & 0.304 \\
\hline
\end{tabular}

\section{INTEPRETATION OF THE RRR VALUES}

The base category of the MNLM model being fitted was independently selected as the first category, owner-occupancy motive for housing demand. According the $p$-values of children's occupancy category relative to the base category, several independent variables were found to have a significant effect on children's occupancy motive for housing demand. The interpretation of these significant variables was performed by observing the RRR of them. These results suggest that men $(R R R=0.50, p<.05,95 \%$ $\mathrm{Cl}=0.29-0.90$ ) have less children's occupancy for housing demand than owner-occupancy motive. On the other hand, both age group categories were found to have significant effects on children's occupancy motive. This motive was more likely to occur relative to owner-occupancy motive when the respondents were aged between 31 and $49(\mathrm{RRR}=5.14, p<.01,95 \% \mathrm{Cl}=2.96-8.94)$ and over the age of $51(\mathrm{RRR}=12.01, p<.01,95 \% \mathrm{Cl}=6.39-22.6)$. Elderly respondents, especially over the age of 


\section{Alkan O., Karaaslan A., Abar H., Çelik A.K., Oktay E. FACTORS AFFECTING MOTIVES FOR HOUSING DEMAND: THE CASE OF A TURKISH PROVINCE}

51, had more tendency to have a house for their children's future than their own occupancy. Similarly, retired respondents $(\mathrm{RRR}=2.83, p<.01,95 \% \mathrm{Cl}=1.35-5.94)$ were more likely think of children's occupancy as a motive for housing demand, while officers (RRR $=2.25, p<.05,95 \% \mathrm{Cl}=1.15-4.40$ ) and workers $(\mathrm{RRR}=1.98, p<.10,95 \% \mathrm{Cl}=1.98-4.11)$ had more children's occupancy motives for housing demand than owner occupancy. In addition, when their spouses were craftsmen or selfemployed $(\mathrm{RRR}=2.12, p<.10,95 \% \mathrm{Cl}=0.97-4.61)$, children's occupancy motive was more likely to occur. The number of individuals in the family $(\mathrm{RRR}=1.48, p<.01,95 \% \mathrm{Cl}=1.23-1.79)$ increases the likelihood of children's occupancy motive nearly 1.5 times more than owner occupancy motive, however the children's occupancy motive was $87 \%$ and $73 \%$ less likely to occur, when the respondents were renters $(R R R=0.13, p<.01,95 \% \mathrm{Cl}=0.08-0.20)$, or had other owner ship features $(R R R=$ $0.27, p<.01,95 \% \mathrm{Cl}=0.14-0.52)$, respectively.

The RRR results of the rental income category showed that male respondents $(\mathrm{RRR}=0.52, p<.05$, $95 \% \mathrm{Cl}=0.28-0.96$ ) had almost $50 \%$ less tendency to have rental income motive for housing demand than owner occupancy motive. Both middle-aged (RRR $=2.48, p<.01,95 \% \mathrm{Cl}=1.48-4.16)$ and elderly $(R R R=1.98, p<.05,95 \% \mathrm{Cl}=1.00-3.91)$ respondents increase the likelihood of rental income motive relative to owner occupancy motive. All occupation categories had a significant impact on the rental income motive, where this motive was more likely to occur when the respondents were retired $(\mathrm{RRR}=5.40, p<.01,95 \% \mathrm{Cl}=1.86-15.7)$, craftsmen or self-employed $(\mathrm{RRR}=3.62, p<.01$, $95 \% \mathrm{Cl}=1.52-8.61)$, officers (RRR $=2.83, p<.01,95 \% \mathrm{Cl}=1.18-6.81)$, or workers (RRR $=2.73, p$ $<.10,95 \% \mathrm{Cl}=0.99-7.53)$. Also, when the respondents' spouses were craftsmen or self-employed (RRR $=2.11, p<.10,95 \% \mathrm{Cl}=0.92-4.86)$, the rental income motive was approximately two times more likely to occur than owner occupancy. Both middle-income $(\mathrm{RRR}=2.23, p<.01,95 \% \mathrm{Cl}=1.36-$ 3.66) and high-income $(\mathrm{RRR}=2.10, p<.10,95 \% \mathrm{Cl}=0.99-4.43)$ respondents increase the likelihood of rental income motive relative to owner occupancy motive. Not surprising, renters (RRR $=0.07, p<$ $.10,95 \% \mathrm{Cl}=0.03-0.13$ ) were $93 \%$ less likely to have rental income motive, while the number of real estate ownership $(\mathrm{RRR}=1.50, p<.01,95 \% \mathrm{Cl}=1.21-1.87) 1.50$ times increase the likelihood of the rental income motive relative to owner occupancy motive.

The estimation results suggested that men were ( $R R R=0.88, p<.01,95 \% \mathrm{Cl}=0.49-1.59) 12 \%$ less likely to have investment motive than owner occupancy. The investment motive was almost two times more likely to occur for middle-aged respondents ( $R R R=1.96, p<.01,95 \% \mathrm{Cl}=1.25-3.07)$. This motive was also more likely to occur for workers (RRR $=2.61, p<.10,95 \% \mathrm{Cl}=0.95-7.18$ ), for officers (RRR $=3.03, p<.05,95 \% \mathrm{Cl}=1.26-7.27$ ), for craftsmen or self-employed (RRR $=4.99, p<$ $.01,95 \% \mathrm{Cl}=2.11-11.8)$, and for retired respondents $(\mathrm{RRR}=5.04, p<.01,95 \% \mathrm{Cl}=1.71-14.9)$. 
Otherwise, the investment motive was almost two times more likely to ocur than owner-occupancy motive when therespondents' spouse was officer (RRR $=1.78, p<.10,95 \% \mathrm{Cl}=0.98-3.22)$. Again, both middle-income $(\mathrm{RRR}=3.51, p<.01,95 \% \mathrm{Cl}=2.20-5.60)$ and high-income $(\mathrm{RRR}=2.89, p<.01$, $95 \% \mathrm{Cl}=1.44-5.80$ ) respondents increase the likelihood of investment motive relative to owner occupancy motive. The investment motive was $89 \%$ and $63 \%$ less likely to occur for renters (RRR $=$ $0.11, p<.01,95 \% \mathrm{Cl}=0.07-0.19)$ and for other ownership features (RRR $=0.37, p<.01,95 \% \mathrm{Cl}=$ $0.19-0.69)$, respectively.

\section{CONCLUSIONS}

Recent advances in industrial sectors bring about the rapid urbanization, especially in developing countries including Turkey. This rapid urbanization will naturally lead to residential problems and even excess housing demand. The phenomenon can be motived by owner and children's occupancy, rental income and investment. This study was also conducted in parallel with these increasing motives. The MNLM estimation results suggest that men are more likely to have owner occupancy tendency relative to other three motives for housing demand. Elderly respondents, especially over the age of 51 , were motived by children's occupancy motives for their housing demand. In addition, the respondents aged between 31 and 49 have also more children's occupancy motive relative to owner occupancy. Besides, retired respondents and officers think of housing demand as a means of children's future. The estimation results also suggest that occupation is the most significant factor affecting the rental income motive for housing demand in Erzurum city. Mostly retired respondents consider housing as a rental income mediator, followed by craftsmen or self-employed, officers, and workers, respectively. Middleaged and elderly people have rental income motives than owner occupancy. The occupation factor revisits as the most significant factor affecting the investment motive for housing demand, while retired respondents are more likely to have investment motive, as well as craftsmen or self-employed. In general, the motives for housing demand were effected by several indicators, most significantly age and occupation factors guide people to direct their tendencies.

\section{REFERENCES}

Ahmad, S., Choi, M. J. \& Ko, J. (2013) Qualitative and quantitative demand for slum and non-slum in Delhi: Empirical evidences from household data, Habitat International, 38, pp. 90-99. doi:10.1016/j.habitatint.2012.02.003

Aktaş, N. E. \& Özsoy, A. (1998) Spatial adaptability and flexibility as parameters of user satisfaction for quality housing, Building and Environment, 33(5), pp. 315-323. doi:10.1016/S0360-1323(97)000504 
Attanasio, O. P., Bottazi, R., Low, H. W., Nesheim, L. \& Wakefield, M. (2012) Modelling the demand for housing over the life cycle, Review of Economic Dynamics, 15(1), pp. 1-18. doi:10.1016/j.red.2011.09.001

Baharoglu, D. (1996) Housing supply under different economic development strategies and the forms of state intervention: The experience of Turkey, Habitat International, 20(1), pp. 43-60. doi:10.1016/0197-3975(95)00033-X

Barrios García, J. A. \& Rodríguez Hernández, J. E. (2008) Housing demand in Spain according to dwelling type: Microeconomic evidence, Regional Science and Urban Economics, 38(4), pp. 363377. doi:10.1016/j.regsciurbeco.2008.02.002

Borooah, V. K. (2002) Logit and Probit: Ordered and Multinomial Models. Thousand Oaks, Sage Publications, Inc.

Börsch-Supan, A., Heiss, F. \& Seko, M. (2001) Housing demand in Germany and Japan, Journal of Housing Economics, 10(3), pp. 229-252. doi:10.1016/jhec.2001.0295

Cesa-Bianchi, A. (2013) Housing cycles and macroeconomic fluctuations: A global perspective, Journal of International Money and Finance, 37, pp. 215-238. doi:10.1016/j.jimonfin.2013.06.004

Chatterjee, S. \& Hadi, A. S. (2006) Regression Analysis by Example. New Jersey: John Wiley \& Sons, Inc.

Cheng, S. \& Long, J. S. (2007) Testing for IIA in the multinomial logit model, Sociological Methods \& Research, 35(4), pp. 583-600. doi:10.1177/0049124106292361

Cramer, J. S. (2003) Logit Models from Economics and Other Fields. New York: Cambridge University Press.

Dusansky, R. \& Koç, Ç. (2007) The capital gains effect in the demand for housing, Journal of Urban Economics, 61(2), pp. 287-298. doi:10.1016/j.jue.2006.07.008

Feinstein, J. \& McFadden, D. (1987) The dynamics of housing demand by the elderly: Wealth, Cash flow, and demographic effects, In The Economics of Aging, pp. 55-92. Cambridge: National Bureau of Economic Research, Inc.

Goodman, A. C. (1990) Demographics of individual housing demand, Regional Science and Urban Economics, 20(1), pp. 83-102. doi:10.1016/0166-0462(90)90026-Y

Goodman, A. C. (2002) Estimating equilibrium housing demand for "stayers", Journal of Urban Economics, 51(1), pp. 1-24. doi:10.1006/juec.2001.2234

Goodman, A. C. (2003) Following a panel of stayers: Length of stay, tenure choice, and housing demand, Journal of Housing Economics, 12(2), pp. 106-133. doi:10.1016/S1051-1377(03)00017-2

Greene, W. H. (2003) Econometric Analysis. New Jersey: Pearson Education, Inc.

Han, X. (2010) Housing demand in Shanghai: A discrete choice approach, Chinese Economic Review, 21(2), pp. 355-376. doi:10.1016/j.chieco.2010.02.006

Hausman, J. \& McFadden, D. (1984) Specification tests for the multinomial logit model, Econometrica, 52(5), pp. 1219-1240.

Kan, K. (2000) Dynamic modelling of housing tenure choice, Journal of Urban Economics, 48(1), pp. 4669. doi:10.1006/juec.1999.2152 
Kenny, G. (1999) Modelling the demand and supply sides of the housing market: Evidence from Ireland, Economic Modelling, 16(3), pp. 389-409. doi:10.1016/S0264-9993(99)00007-3

Lawal, H. B. (2003) Categorical Analysis with SAS and SPSS Applications. New Jersey: Lawrance Erlbaum Associates, Inc.

Lewis-Beck, M. S. (1980) Applied Regression Analysis: An Introduction. London: Sage Publications, Inc.

Long, J. S. \& Freese, J. (2001) Regression Models for Categorical Dependent Variables Using Stata. Texas: Stata Press.

Ng, S. T., Skitmore, M. \& Wong, K. F. (2008) Using genetic algorithms and linear regression analysis for private housing demand forecast, Building and Environment, 43(6), pp. 1171-1184. doi: 10.1016/j.buildenv.2007.02.017

Özer, H. (2004) Nitel Değişkenli Ekonometrik Modeller Teori ve Bir Uygulama. Ankara: Nobel Yayın Dağıtım.

Pindyck, R. S. \& Rubinfeld, D. L. (1981) Econometric Models \& Economic Forecasts. New York: McGraw-Hill, Inc.

Pugh, C. (2001) The theory and practice of housing sector development for developing countries, 1950 99, Housing Studies, 16(4), pp. 399-423. doi:10.1080/02673030120066527

Rapaport, C. (1997) Housing demand and community choice: An empirical analysis, Journal of Urban Economics, 42(2), pp. 243-260. doi:10.1016/juec.1996.2023

Quigley, J. M. (1976) Housing demand in the short run: An analysis of polytomous choice, In Explorations in Economic Research Volume 3 Number 1, pp. 76-102. Cambridge: National Bureau of Economic Research, Inc.

Özdemir-Sarı, Ö. B. (2014) Empirical investigation of owner-occupiers' reinvestments in housing: The case of Ankara, Turkey, Journal of Housing and the Built Environment, 29(1), pp. 79-104. doi:10.1007/s10901-013-9341-x

Small, K. A. (1987) A discrete choice model for ordered alternatives, Econometrica, 55(2), pp. 409-424.

Tsai, I. (2013) Housing affordability, self-occupancy housing demand and housing price dynamics, Habitat International, 40, pp. 73-81. doi:10.1016/j.habitatint.2013.02.006

Turk, S. S. \& Altes, W. K. K. (2013) The applicability of inclusionary housing (IH) in Turkey, Journal of Housing and the Built Environment, June 2013, doi:10.1007/s10901-013-9358-1

TurkStat. (2011) Address Based Population Registration System Results, 2011. Ankara: Turkish Statistical Institute.

Van Ommeren, J. \& Koopman, M. (2011) Public housing and the value of apartment quality to households, Regional Science and Urban Economics, 41(3), pp. 207-213. doi:10.1016/j.regsciurbeco.2011.02.001

Yetgın, F. \& Lepkova, N. (2007) A comparative analysis on housing policies in Turkey, International Journal of Strategic Property Management, 11(1), pp. 47-64. doi:10.1080/1648715X.2007.9637560

Yonder, A. (1987) Informal land and housing markets: The case of Istanbul, Turkey, Journal of the American Planning Association, 53(2), pp. 213-219. doi:10.1080/01944368708976654

Zabel, J. E. (2004) The demand for housing services, Journal of Housing Economics, 13(1), pp. 16-35. doi:10.1016/j.he.2003.12.002 